\title{
93. 色彩視環境の快適性の定量化
}

\author{
佐川賢 \\ （生命工学工業技術研究所）(筑波技術短期大学)
}

快適な環境の㔊造が話題になっている。視罢境に関しても作業効率から快適性へと新たな評洒の 視点を加兄る必要がある。色彩は視㻴境の中でも特に块適性に占める割合も大きく、重要な裂因と

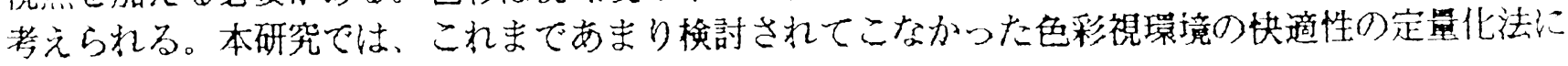
つい、心理物理的手法を用いて検討する。

これまでの幾何学的配色パ夕ンを用いた心理評価の奏駼から色彩の快適性の評価以関して、

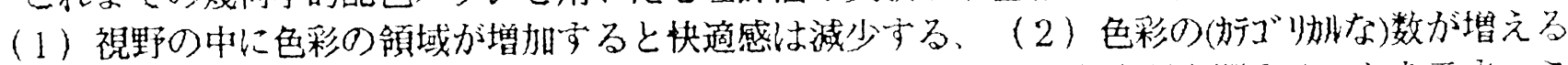
と快適感は滅少する。という結果を得だ”。どちも視野内の彩やかさが影響することを示す。こ の結果を基に、一般の色彩画像の快適性を評価するため、以下の2つの方法を検討した。

\section{〈方法 1 : 配色数法>}

評価すべき色彩画像の中の（心理的）基本色の数で扶適性を評価する。基本色はここで法瞬間提 示された画像の中で記憶される全ての色を单一の色名で報告させた場合の色（がゴ版ラーネーシング） として定義する。図10)様に力ラ一CRT上に色彩画像（价师、風䑁等）を提示し、観測者の報告し た色の数と快適性の主観評価の相関をとると図2のように負の相関が得られる。色彩の数が増える と快適性が減少することを示す。

〈万法 2 : 彩度变換法〉

色彩画像を無彩色凡多から原有彩色八多まで彩度を連続的に変化させ、锶測者自ら快適と思わ礼

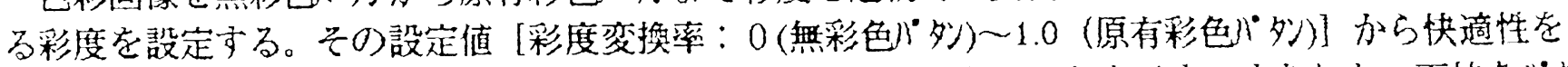

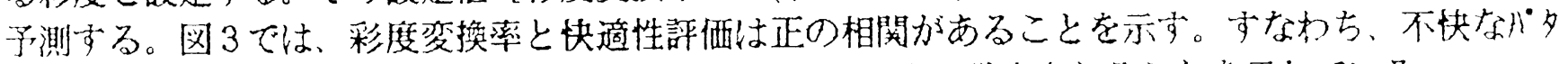
ン㤃り低彩度に設定され、扶適なパタンは元パタンの彩度に設定されることを示している。

以上より、今回検討した2つの方法はともに色彩画像の快適性を評価する上で有効であることが 判明した。

文献：1）佐川堅、清水豊；色彩川多-ンの心理評価、色彩学会誌（1995）印剧中
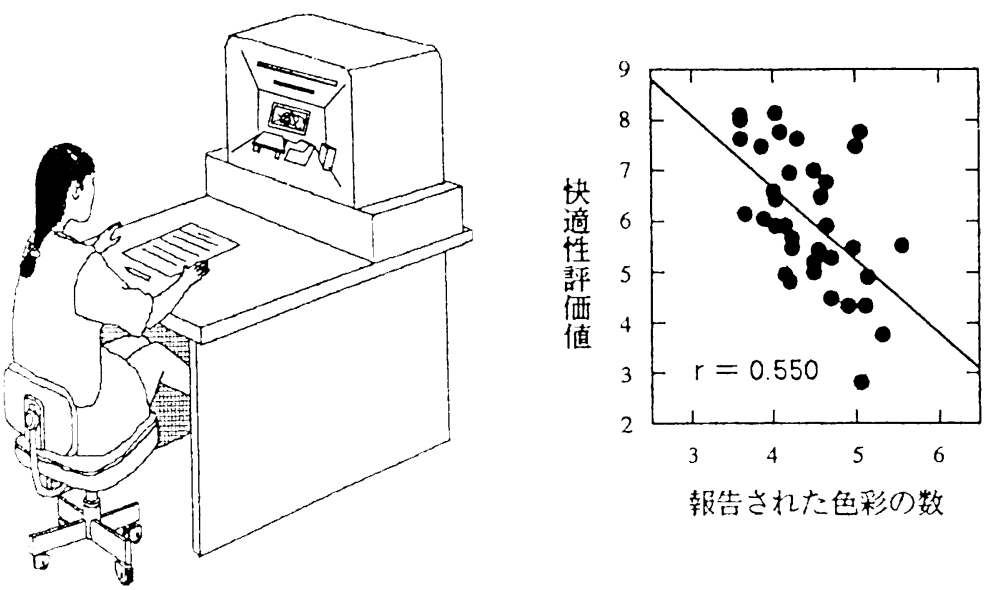

図2，色彩数と快適性との関係

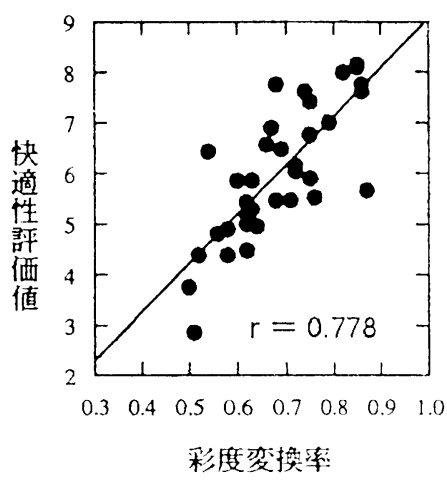

図 3.彩度変換率と快適性との関係 